\title{
Spatial Scales of Pollen and Seed-Mediated Gene Flow in Tropical Rain Forest Trees
}

\author{
Christopher W. Dick • Olivier J. Hardy • \\ F. Andrew Jones • Rémy J. Petit
}

Received: 2 October 2007 / Accepted: 20 December 2007 /Published online: 26 February 2008

(C) Springer Science + Business Media, LLC 2008

\begin{abstract}
Gene flow via seed and pollen is a primary determinant of genetic and species diversity in plant communities at different spatial scales. This paper reviews studies of gene flow and population genetic structure in tropical rain forest trees and places them in ecological and biogeographic context. Although much pollination is among nearest neighbors, an increasing number of genetic studies report pollination ranging from $0.5-14 \mathrm{~km}$ for canopy tree species, resulting in extensive breeding areas in
\end{abstract}

Communicated by Paul H. Moore

Electronic supplementary material The online version of this article (doi:10.1007/s12042-007-9006-6) contains supplementary material, which is available to authorized users.

\section{W. Dick}

Department of Ecology and Evolutionary Biology and Herbarium, University of Michigan,

830 North University Avenue,

Ann Arbor, MI 48109, USA

C. W. Dick $(\bowtie) \cdot$ F. A. Jones

Smithsonian Tropical Research Institute,

P.O. Box 0843-03092, Balboa Ancón,

Republic of Panama

e-mail: cwdick@umich.edu

F. A. Jones

e-mail: jonesf@si.edu

O. J. Hardy

Behavioural and Evolutionary Ecology Unit,

Université Libre de Bruxelles,

Brussels, Belgium

e-mail: ohardy@ulb.ac.be

\section{R. J. Petit}

Institut National de la Recherche Agronomique,

UMR Biodiversity, Genes and Communities,

33610 Cestas, France

e-mail: petit@pierroton.inra.fr disturbed and undisturbed rain forest. Direct genetic measures of seed dispersal are still rare; however, studies of fine scale spatial genetic structure (SGS) indicate that the bulk of effective seed dispersal occurs at local scales, and we found no difference in SGS ( $S p$ statistic) between temperate $(N=24$ species $)$ and tropical forest trees $(N=15)$. Our analysis did find significantly higher genetic differentiation in tropical trees $\left(F_{\mathrm{ST}}=0.177 ; N=42\right)$ than in temperate forest trees $\left(F_{\mathrm{ST}}=0.116 ; N=82\right)$. This may be due to the fact that tropical trees experience low but significant rates of self-fertilization and bi-parental inbreeding, whereas half of the temperate tree species in our survey are wind pollinated and are more strictly allogamous. Genetic drift may also be more pronounced in tropical trees due to the low population densities of most species.

Keywords Mating system · Pollination - Seed dispersal . Spatial genetic structure $\cdot$ Population differentiation

If the traveler notices a particular species and wishes to find more like it, he may often turn his eyes in vain in every direction. Trees of varied forms, dimensions, and colours are around him, but he rarely sees any one of them repeated. Time after time he goes towards a tree which looks like the one he seeks, but a closer examination proves it to be distinct. A. R. Wallace 1878 [126]

\section{Introduction}

Lowland tropical rain forests are renowned for their woody plant diversity. Alfred Russel Wallace [126] famously wrote that one could walk a half mile through an Amazon forest 
without seeing two of the same tree species. Indeed, some forests in South America and Southeast Asia contain as many as 450 tree, shrub and liana species per hectare [75], making it difficult for the world's most gifted taxonomists to keep track of this biological variation.

As a correlate of species richness, tropical forest trees typically occur in low population densities [62] and rely almost exclusively on animals for pollination [11]. In light of their low population densities, asynchronous flowering, and animal pollination, Corner [25] and Baker [9] posited that tropical trees should be frequently self-fertilized. Federov [38] further suggested that genetic drift in highly inbred tropical trees should promote speciation over relatively limited spatial scales. Fedorov's hypothesis provided a micro-evolutionary explanation for the latitudinal gradient in tropical tree diversity as well as predictions about the mating systems and spatial scale of gene flow in tropical trees. In particular, the early authors assumed that gene flow in tropical trees was restricted and successful reproduction required the ability to self-pollinate. Researchers at the time did not have data on pollen or seed dispersal distances for any tropical tree species. The hypothesis instigated several decades of genetic research on tropical plants [6, 42, 51, 118].

Given the current high rates of destruction and fragmentation of tropical forests, tropical tree populations are experiencing contractions of population sizes and some species may be more affected by demographic stochasticity and genetic drift than at any other time in their histories. Altered patterns of gene flow and genetic structure have implications for mating systems, levels of inbreeding, and the maintenance of genetic diversity. Hamrick [50] has argued that because of their extensive documented pollen flow, long lifespan, and high genetic diversity, trees in general may be less vulnerable to anthropogenic changes than other organisms. However, this may not apply to tropical trees species that are highly dependent on animals for all aspects of their reproduction and regeneration [97, $127]$.

\section{Scope of Review}

This paper reviews recent literature pertaining to the spatial scale of gene flow and population genetic structure in tropical trees. The spatial scales range from stand-level analyses of pollen and seed dispersal to indirect estimates of historical gene flow at regional scales, including rare long distance dispersal events that result in geographic range expansions. The review addresses the following questions: (1) What is the spatial scale of gene flow by pollen and seed in tropical forest trees? (2) To what extent does life history variation in trees, including seed disperser and pollinator identity, determine distances of gene dispersal? (3) What is the spatial scale of population genetic differentiation in tropical trees, and (4) does the degree of genetic differentiation, at local and regional spatial scales, differ between tropical and temperate forest trees?

The present paper builds upon previous reviews of mating system [83, 128], genetic diversity [53, 54], and fine scale spatial genetic structure [57] of tropical plants. This review is unique in its attempt to link gene flow processes at ecologically and biogeographically relevant temporal and spatial scales. Our focus is on tree species native to lowland humid tropical forests, which we refer to as tropical rain forests. Given the magnitude of species diversity in these forests, and the comparative paucity of genetic research on tropical trees, there are predictably many gaps in the literature with respect to geographic distributions, life histories, and phylogenetic sampling of the study taxa. Some of these deficiencies are highlighted as considerations for future research.

\section{Determinants of Gene Flow}

\section{Pollinators}

A striking contrast between tropical and temperate forests is the paucity of wind pollination in the tropical rain forests. Low population densities preclude efficient wind pollination for trees in species-rich forests [103]. Furthermore, high humidity dampens pollen grains, and heavy rains wash pollen from the air [78, 121]. The Neotropical tree genus Cecropia (Urticaceae), which is comprised of light-demanding pioneers with dense local populations, is among the fewer than $2 \%$ of putative wind-pollinated tropical forest tree species [11]. Although wind pollination has been proposed as a pollination syndrome for shade-tolerant dioecious trees with small, inconspicuous flowers, including many understory species [17], these assertions await experimental confirmation.

The behavioral differences between classes of animal pollinators partly determine the distances over which pollen is transported. In tropical moist forests around the world, bees are the predominant class of pollinators [11, 85]. Hummingbirds and euglossine bees are moderately specialized pollinators restricted to the Neotropics. Tiny aganoid wasps $(2-3 \mathrm{~mm})$ are highly specialized pollinators of fig trees (Ficus) with a pantropical distribution. Besides regional variation in pollinator identity, the pollinator community can vary among forest strata. For example, understory trees in Costa Rica received more visits by specialized pollinators such as hummingbirds, large beetles, and sphingid moths than did canopy trees [11]. 
Seed Dispersers

Howe and Smallwood [60] estimated that animals disperse more than $70 \%$ of all tropical lowland tree species. However, unlike specialist pollinator syndromes observed in some tropical trees, such as figs, there have been few if any documented cases of specialist seed dispersers. Tropical tree species generally have multiple seed dispersal agents and these agents are shared among species, although their effectiveness, with respect to host plant reproductive success, varies considerably $[59,112,121]$. The proportion of winddispersed tree species varies along a precipitation gradient. In Costa Rica wind-dispersed trees range from $4 \%$ of the species in moist forests (La Selva) to 23\% in dry forests (Santa Rosa; [43]). Wind dispersal of seeds is more frequently found in canopy or canopy-emergent trees than among trees of the forest understory ([121], Table 4.5). As with pollinators, there is some variation in seed dispersal mode among the strata of rain forest trees. In particular, many understory trees have fleshy fruits that are dispersed by sedentary, forest-interior birds that avoid open habitats [29, 44].

\section{Phenology}

In the Neotropics, most tree species flower during the dry season and set fruit at the beginning of the wet season [65]. In the aseasonal Dipterocarp forests of Southeast Asia, synchronized, supra-annual flowering triggered by el Niño events [7] causes massive fruit production (masting) by a large number of tree species in the Dipterocarpaceae and other families [4, 110]. The burst of community-level flowering attracts migratory pollinators such as Apis dorsata [71] and increases the population density of small, ephemeral pollinators. Masting attracts migratory animals such as wild pigs, and satiates seed predators, such that some percentage of seeds escapes predation. Phenological patterns within species also impacts pollinator behavior and spatial patterns of gene flow [79]. "Big bang" flowering, in which large numbers of flowers are produced over a short time frame, attracts many floral visitors, but does not encourage outcross pollination [40]. In such mass-flowering trees, most of the outcross pollination may happen toward the end of the flowering period, when diminishing floral rewards compel pollinators to visit other trees [119]. Tree species with asynchronous flowering, such as figs (Ficus), may flower throughout the year, but at any given month only a small proportion (less than $10 \%$ ) of adult trees can interbreed, contributing to long distances of inter-tree pollinations [93]. Flowering phenology thus affects spatial patterns of gene flow by altering the resource base that drives the foraging behavior of pollinators and seed dispersing animals.
Gender Distribution

Dioecy is consistently more frequent in tropical trees than in temperate ones $[12,123]$. Gender distribution has obvious effects on mating system. In dioecious taxa, the mating system is necessarily $100 \%$ outcrossed, although biparental inbreeding remains possible. In contrast to many monoecious wind-pollinated trees, many tropical trees are hermaphroditic, but exhibit self-incompatibility [14]. Gender distribution will also affect the density of potential mates and hence spatial patterns of gene flow. In dioecious taxa, only female individuals disperse seeds and only male individuals disperse pollen; the effect on gene flow can be exacerbated if sex ratio differs from one [13]. Interestingly, most dioecious species have fleshy fruits [123], which is an efficient strategy for moving seeds over long distances [84].

\section{Outcrossing Rates}

The outcrossing rate $(t)$ is a central feature of the mating system. Plants are categorized as being primarily selffertilized $(t<20 \%)$, outcrossed $(t>80 \%)$ or as having a mixed mating system with bimodal distribution of selffertilizing and outcrossing individuals [45]. Species that permit a high level of self-fertilization are expected to have an excess of homozygotes (high $F_{\text {IS }}$ ) and may experience relatively high levels of population differentiation (high $\left.F_{\mathrm{ST}}\right)$ resulting from genetic drift. Tropical rain forest trees are considered to be primarily outcrossed, due to the prevalence of self-incompatibility mechanisms and gender segregation (dioecy and dichogamy; [14]). As pointed out above, and in contrast with temperate trees [102], most tropical trees are biotically pollinated; this pollination syndrome has been shown to be associated with mixedmating systems $[1,10,45]$, perhaps because animal pollinators are not as reliable as wind [73, 80, 111]. Using a limited number of allozyme loci, it can be difficult to tell if homozygous seeds are derived from self-fertilization or bi-parental inbreeding. In studies using hypervariable microsatellite loci, however, it is clear that many primarily outcrossing tropical trees produce large numbers of seeds through self-fertilization [26, 32, 63, 128].

Because outcrossing rates are known to vary across habitat types [39] and population densities for some tree species [83], we tabulated mating system studies that sampled maternal trees from low and high-density populations (Table 1). Most of these studies were comparisons of disturbed (low population density) and undisturbed (high population density) forests. While only a few of the studies provided confidence intervals around estimates of $t, 15$ of the 21 studies report a lower multi-locus outcrossing rate 
Table 1 Mating system at low vs high density in tropical trees

\begin{tabular}{|c|c|c|c|c|c|c|}
\hline Tree species & Country & Pollinator & $\begin{array}{l}\text { Low } \\
\text { density }\end{array}$ & $\begin{array}{l}\text { High } \\
\text { density }\end{array}$ & Experimental design & Reference \\
\hline $\begin{array}{l}\text { Carapa guianensis } \\
\text { (Meliaceae) }\end{array}$ & Brazil & Small insect & 0.92 & 0.93 & $\begin{array}{l}\text { Two groups of low and high mean } \\
\text { number of neighbours }\end{array}$ & {$[20]$} \\
\hline $\begin{array}{l}\text { Carapa guianensis } \\
\text { (Meliaceae) }\end{array}$ & Costa Rica & Small insect & 0.97 & 0.99 & Logged vs primary forest & {$[46]$} \\
\hline Carapa procera (Meliaceae) & French Guiana & Small insect & 0.63 & 0.85 & Logged vs control & [40] \\
\hline $\begin{array}{l}\text { Caryocar brasiliense } \\
\text { (Caryocaraceae) }\end{array}$ & Brazil & Bats & $0.77^{\mathrm{a}}$ & $0.84^{\mathrm{a}}$ & Populations of differing density & {$[22]$} \\
\hline $\begin{array}{l}\text { Cavanillesia platanifolia } \\
\text { (Malvaceae) }\end{array}$ & Panama & $\begin{array}{l}\text { Hawk moths, } \\
\text { monkeys, bats }\end{array}$ & 0.21 & 0.57 & $\begin{array}{l}\text { Across years differing in } \\
\text { density of flowering trees }\end{array}$ & [88] \\
\hline $\begin{array}{l}\text { Ceiba aesculifolia } \\
\text { (Malvaceae) }\end{array}$ & Mexico & Bats & 0.97 & 0.96 & Fragment vs forest & [101] \\
\hline $\begin{array}{l}\text { Ceiba pentandra } \\
\text { (Malvaceae) }\end{array}$ & Mexico & Bats & 0.91 & 0.90 & Fragment vs forest & [101] \\
\hline Dinizia excelsa (Fabaceae) & Brazil & Small insects & 0.86 & 0.90 & Pasture vs forest & {$[31,32]$} \\
\hline $\begin{array}{l}\text { Dryobalanops aromatica } \\
\text { (Dipterocarpaceae) }\end{array}$ & Malaysia & Large bees & 0.77 & 0.92 & Logged vs primary forest & [74] \\
\hline $\begin{array}{l}\text { Entandrophragma cylindricum } \\
\text { (Meliaceae) }\end{array}$ & Cameroon & Bees and moths & 0.98 & 0.98 & Before and after logging & [81] \\
\hline $\begin{array}{l}\text { Enterolobium cyclocarpum } \\
\text { (Fabaceae) }\end{array}$ & Costa Rica & $\begin{array}{l}\text { Insects (moths, } \\
\text { bees, beetles) }\end{array}$ & 1.00 & 1.00 & Pastures vs forest & [108] \\
\hline $\begin{array}{l}\text { Helicteres brevispira } \\
\text { (Sterculiaceae) }\end{array}$ & Brazil & Hummingbirds & 0.49 & 0.66 & $\begin{array}{l}\text { Low and high density zones } \\
\text { in the same population }\end{array}$ & [39] \\
\hline Leucaena esculenta (Fabaceae) & Mexico & Small insects & 0.64 & 0.64 & Managed vs unmanaged & {$[131]$} \\
\hline $\begin{array}{l}\text { Pachira quinata } \\
\text { (Malvaceae) }\end{array}$ & Costa Rica & $\begin{array}{l}\text { Bats and sphingid } \\
\text { moths }\end{array}$ & 0.78 & 0.91 & Isolated vs. continuous & [41] \\
\hline Balizia elegans (Fabaceae) & Costa Rica & Sphingid moths & 0.97 & 0.99 & $\begin{array}{l}\text { Across years differing in density } \\
\text { of flowering trees }\end{array}$ & [48] \\
\hline $\begin{array}{l}\text { Pterocarpus macrocarpus } \\
\text { (Fabaceae) }\end{array}$ & Thailand & Insects & 0.74 & 0.95 & Populations of differing density & [77] \\
\hline Samanea saman (Fabaceae) & Costa Rica & Sphingid moths & 0.91 & 0.99 & Isolated vs. Continuous forest & [18] \\
\hline Sextonia rubra (Lauraceae) & French Guiana & Small insects & 0.95 & 0.90 & $\begin{array}{l}\text { Two groups of low and high mean } \\
\text { number of neighbours }\end{array}$ & {$[20,21]$} \\
\hline $\begin{array}{l}\text { Shorea curtisii } \\
\text { (Dipterocarpaceae) }\end{array}$ & Malaysia & Small insects & 0.52 & 0.93 & Logged vs primary forest & [96] \\
\hline $\begin{array}{l}\text { Shorea megistophylla } \\
\text { (Dipterocarpaceae) }\end{array}$ & Sri Lanka & Large bees (Apis) & 0.71 & 0.87 & Logged vs primary forest & [89] \\
\hline $\begin{array}{l}\text { Symphonia globulifera } \\
\text { (Clusiaceae) }\end{array}$ & Costa Rica & Hummingbirds & 0.74 & 0.90 & Pasture vs forest & [2] \\
\hline
\end{tabular}

The multilocus outcrossing rate $\left(t_{\mathrm{m}}\right)$ is presented in columns 3 and 4 for low and high population densities of trees.

${ }^{\mathrm{a}} t_{\mathrm{s}}\left(t_{\mathrm{m}}=1\right)$

$\left(t_{\mathrm{m}}\right)$ in the lower-density population, indicating a trend toward higher inbreeding in spatially isolated trees. There is a need to examine the mating patterns and fitness of trees in naturally occurring low and high-density populations to determine if low-density tree populations experience reduced reproductive success due to pollinator limitation or inbreeding.

\section{Inbreeding Depression}

Inbreeding depression is particularly strong in trees ([99] and references therein). Plant mating system studies have detected inbreeding depression as an increase in heterozygosity with age class when comparing seeds with seedlings or older plants. Early allozyme studies of the legume tree 
Platypodium elegans, for example, found outcrossing rates of $>80 \%$ based on genotypes of seedlings [52,87], but a microsatellite analysis of seeds from the same population found outcrossing rates of $60 \%$ [63]. The higher outcrossing estimate for seedlings is presumably the result of selection against homozygous seeds, many of which were aborted or had lower seed weights than outcrossed seeds. There is a generally positive correlation between age/size and heterozygosity across life stages in tropical trees (reviewed in [3, 67]). These results underscore the importance of outcross pollination for the fitness of tropical tree populations, but it is unclear whether tropical trees differ from temperate trees in this respect.

\section{Spatial Scales of Seed Dispersal}

Among other hypotheses, the efficiency of seed dispersal has been invoked to explain the species richness of tropical forests $[75,130]$. Seed dispersal plays an important role in permitting seedlings to escape taxon-specific pathogens and herbivores that plague maternal trees within the local community $[24,66]$, and by colonizing open space for populations to escape local extinction in the metacommunity $[61,106]$. As a component of recruitment limitation, restricted seed dispersal contributes to species diversity by allowing for inferior competitors to persist when they fail to encounter a superior competitor [64, 120].

Whereas paternity analysis is frequently used to measure pollen dispersal distances, similar direct estimates of seed dispersal distances using genetic markers are rare. One reason is that maternally inherited cpDNA variation is generally too low to allow for maternal exclusion [100]. At least three genetic techniques have been used to infer seed dispersal in tropical trees: (1) parental exclusion of hermaphroditic or monoecious species (biparental exclusion) using nuclear DNA markers [2, 113], (2) parental exclusion of dioecious species (uniparental exclusion) in which the maternal parent can be distinguished unambiguously [56], and (3) exact identification of seed parents by genotyping maternal tissue (seed coat, fruit tissue, or attached samaras) from seeds [68, 127].

Jones et al. [68] used the maternal tissue approach to study seed dispersal in the wind dispersed Neotropical tree Jacaranda copaia within a 84-ha forest census plot on Barro Colorado Island, Panama. Although some seeds arrived from outside the plot $(\geq 700 \mathrm{~m})$, most seeds $(75 \%)$ moved less than $100 \mathrm{~m}$ from the maternal trees. Born et al. [15] conducted microsatellite-based parentage analyses of saplings in the wind-dispersed pioneer tree Aucoumea klaineana (Burseraceae) at the margin of a forest colonization front in Gabon. Because the species is dioecious, seed dispersal events leading to establishment could be reconstructed unambiguously. Dispersal distances ranged from 20 to $258 \mathrm{~m}$ with a mean of $118 \mathrm{~m}$.

\section{Long Distance Seed Dispersal}

Long distance dispersal (LDD) occurs at both ecological and biogeographic spatial scales. At the scale of forest stands (e.g. 50-ha), long distance seed dispersal may encompass the most distant seed dispersal events within a given season or generation $[56,68]$. In an ecological context, LDD occurs over kilometers at frequencies of decades. Long distance dispersal has a different meaning in the biogeographic literature, where it refers to rare dispersal events that result in the expansion of geographic ranges [94, 104]. Successful "sweepstakes dispersal" [115], which carries seeds across oceans, may occur once during the course of a species' lifespan.

Sweepstakes dispersal can be inferred from DNA sequence phylogeography and molecular clock methods [105]. If the genetic divergence between disjunct populations is much less than expected under the time scale implied by a vicariance hypothesis, then dispersal is inferred as the cause of the population disjunction. This approach was used to infer dispersal from Africa to the Neotropics of Symphonia globulifera [31]. The fossil-based analysis indicated that three separate oceanic dispersal events led to the establishment of S. globulifera populations in Central America, South America and the West Indies over a time frame of approximately 16 million years. A similar genetic analysis of the kapok tree Ceiba pentandra (Malvaceae) demonstrated that African populations established through oceanic dispersal from a Neotropical source at least 13,000 years before present [33]. Neither Symphonia globulifera nor Ceiba pentandra is specifically adapted to marine dispersal. In species adapted for water dispersal, such as mangroves [95], trans-Atlantic dispersal may bridge evolutionary and ecological time scales.

Sweepstakes dispersal events are important in determining floristic similarities of disjunct tropical forests. Pennington and Dick [98] evaluated the biogeographic origins of tree lineages in a 25 -ha forest inventory plot in Ecuador [122]. Based upon published fossil-calibrated angiosperm phylogenies, the authors concluded that at least $21 \%$ of the species $(N=232)$, and $20 \%$ of the stems $(N=$ $30,156)$ were derived from lineages that had arrived in South America via the Isthmus of Panama or by long distance oceanic dispersal. This is probably an underestimate, because it did not include more recent studies that demonstrate recent, non-South American origins of important families like Meliaceae [86]. 


\section{Pollen Dispersal}

Prior to the broad use of genetic markers, pollen dispersal was studied primarily by tracking pollen and pollinators with dyes or other visual markers (e.g. [129]). Such studies provide insights into pollinator foraging behavior, but they can underestimate pollen dispersal distances due to the phenomenon of pollen carryover, in which pollen may be carried to several plants before being deposited on a stigma [76]. Moreover, pollen tracking and pollinator observations are limited to local spatial scales and to relatively small plants.

Genetic techniques have revolutionized our understanding of pollen dispersal in tree populations $[116,128]$. Rare alleles and fractional paternity are the primary methods of genetic analysis used to infer paternity using allozyme data (e.g. [16, 82, 118]). Study species that produce fruits containing single-sired seed arrays, such as figs and some mimosoid legumes [5, 93], are amenable to precise paternity analyses using allozymes. Highly variable microsatellite DNA markers have opened the doors to precise paternity assignments and have become the marker of choice for pollen dispersal studies. However, paternity inference is useful to the extent that most potential pollen donors have been accurately genotyped. Instead, the TwoGener [117] and Kindist [107] methods provide indirect estimates of pollen dispersal distances, based on genetic differentiation in the pollen allele pools $\left(\Phi_{\mathrm{FT}}\right)$ of maternal trees. The methods are useful in studying pollenmediated gene flow in stands of tropical forest trees in which it is difficult to locate all potential reproductive adults $[28,32,125]$. The methods are also amenable to statistical testing of differences in mean pollen dispersal distances among sites or habitat types [21, 32].

\section{Pollen Dispersal Distances}

One of the intriguing results of paternity analyses is the unexpected long distances of pollen dispersal, not only in wind-pollinated temperate trees but also in animal-pollinated trees from both temperate and tropical regions ([91, 99], Table 1). Studies confined to mapped populations of trees in 50-ha plots often infer pollen flow from outside of the plots, which implies pollination distances of more than $500 \mathrm{~m}$, even for tree species pollinated by small insects $[52,118]$.

Several studies have directly measured pollen dispersal distances for trees pollinated by large bees (Table 2). The Neotropical studies were all performed on legume trees with large floral displays [27, 52, 73, 82], while the two Paleotropical studies were performed on Dipterocarp trees (Dipterocarpaceae) visited by the giant honeybee Apis dorsata [70, 72]. Pollen flow exceeded $600 \mathrm{~m}$ in all of these studies. In the papilionoid legume Platypodium elegans, for example, $25 \%$ of the pollen was moved greater than $750 \mathrm{~m}$ [52]. The mean pollen dispersal distance of the two Dipterocarp species was estimated as 191 to $222 \mathrm{~m}$.

Pollen dispersal distances for trees visited by small insects are available for a number of angiosperm families [20, 32, 118, 125]. Small insects unsurprisingly disperse pollen over smaller distances than do large bees, and maximum pollen dispersal in closed-canopy forests often does not exceed 300 meters (Table 2). Stacy et al. [118] reported that $62 \%$ of pollen traveled $\geq 210 \mathrm{~m}$ in Calophyllum longifolium (Clusiacae). A very small proportion ( $5 \%)$ of pollen moved $\geq 300 \mathrm{~m}$ in Spondias mombin (Anacardiacae); and only $1 \%$ of pollen moved $\geq 130 \mathrm{~m}$ in Turpinia occidentalis (Staphyleaceae).

Studies of low-density, remnant tree populations in agroecosystems have documented exceptionally long distance gene flow among spatially isolated trees, even for species visited primarily by small insects, despite the decreased outcrossing rate often observed at low density (Table 1; [83]). Chase et al. [19] documented pollen dispersal $\geq 600 \mathrm{~m}$ over pasture in Costa Rican populations of the legume tree Pithecellobium elegans (=Balizia elegans), which is thought to be pollinated by large Sphingid moths. Similar studies of isolated pasture trees of Swietenia humilis (Meliaceae) in Honduras and Dinizia excelsa (Fabaceae) in Brazil reported pollination distances of 4.5 and $3.2 \mathrm{~km}$, respectively. The latter two species are pollinated by a diverse array of small insects (bees, beetles, and butterflies). In the pasture population of $D$. excelsa, however, native pollinators were replaced by large numbers of Africanized honeybees (Apis mellifera scutellata), which carried pollen kilometers between remnant pasture and forest trees.

Nason and colleagues [92, 93] showed that animaldispersed pollen can move over kilometers in continuous tropical forest. The authors studied pollination in lowdensity populations of figs (Ficus) on Barro Colorado Island (BCI), Panama. Figs have an inverted inflorescence (syconium or fig fruit) and because the pollinating female wasp (termed a foundress) dies in the syconia, a fruit with a single dead wasp contains full sibling seeds. By using single foundress fruit only, the authors reconstructed the complete (diploid) genotypes of the pollen donating trees. With information on the effective density of the fig populations, Nason et al. [93] estimated that pollen was received from a radius of up to $14 \mathrm{~km}$ around centrally located individuals, which implies that these trees have breeding areas spanning 109 to $631 \mathrm{~km}^{2}$. These pollination distances are remarkable because fig wasps are tiny (1$2 \mathrm{~mm}$ ), ephemeral (lifespan of 1-3 days) and presumably weak flyers. Fig wasps are probably carried into the air current high over the rain forest canopy. When the speciesspecific fragrance of the host-fig is perceived, the wasps drop to the canopy and fly toward the receptive fig tree. 
Table 2 Estimates of pollen dispersal distances for tropical forest trees

\begin{tabular}{|c|c|c|c|c|c|c|c|}
\hline Tree species & Country & $\begin{array}{l}\text { d.b.h. } \\
\mathrm{cm}^{\mathrm{a}}\end{array}$ & $\begin{array}{l}\text { Density } \\
\left(\mathrm{ha}^{-1)}\right.\end{array}$ & Marker & Pollinator & Pollen flow (m and km) & Reference \\
\hline Dinizia excelsa (Fabaceae) & Brazil & $\geq 40$ & 0.017 & M & Small insects & 188 and $212 \mathrm{~m}(\mathrm{TG})$ & {$[31,32]$} \\
\hline Sextonia rubra (Lauraceae) & $\begin{array}{l}\text { French } \\
\text { Guiana }\end{array}$ & $\geq 10$ & 2.4 & M & Small insects & 65 and $80 \mathrm{~m}(\mathrm{TG})$ & $\begin{array}{c}{[20,21,} \\
125]\end{array}$ \\
\hline $\begin{array}{l}\text { Calophyllum longifolium } \\
\text { (Clusiaceae) }\end{array}$ & Panama & $\geq 18$ & 0.028 & A & Small insects & $\geq 210 \mathrm{~m}(62 \%$ of pollen $)$ & [118] \\
\hline $\begin{array}{l}\text { Spondias mombin } \\
\text { (Anacardiaceae) }\end{array}$ & Panama & $\geq 20$ & 0.33 & A & Small insects & $\geq 300 \mathrm{~m}$ (5\% of pollen) & [118] \\
\hline $\begin{array}{l}\text { Turpinia occidentalis } \\
\text { (Staphyleaceae) }\end{array}$ & Panama & $\geq 20$ & 1.27 & A & Small insects & $\geq 130 \mathrm{~m}$ ( $1 \%$ of pollen) & [118] \\
\hline Carapa guianensis (Meliaceae) & Brazil & $\geq 30$ & 2.5 & M & Small insects (butterfly) & 75 and $265 \mathrm{~m}(\mathrm{TG})$ & {$[20,21]$} \\
\hline $\begin{array}{l}\text { Neobalanocarpus heimii } \\
\text { (Dipterocarpaceae) }\end{array}$ & Malaysia & $\geq 30$ & 0.83 & M & Large and mid-sized bees & $\begin{array}{l}191.2 \mathrm{~m}(\text { mean } \pm 104 \mathrm{SD}) \\
\max \geq 663.6\end{array}$ & [72] \\
\hline $\begin{array}{l}\text { Dipterocarpus tempehes } \\
\text { (Dipterocarpaceae) }\end{array}$ & Sarawak & $\geq 50$ & 3.97 & M & $\begin{array}{l}\text { Large bees (year 1) and } \\
\text { moths (year 2) }\end{array}$ & $\begin{array}{l}192 \mathrm{~m} \text { (moths) and } 222 \\
\text { (bees); } \geq 600\end{array}$ & {$[70]$} \\
\hline $\begin{array}{l}\text { Dicorynia guianensis } \\
\text { (Fabaceae) }\end{array}$ & $\begin{array}{l}\text { French } \\
\text { Guiana }\end{array}$ & $\geq 20$ & 3.925 & M & Large bees & $\geq 700 \mathrm{~m}$ & [71] \\
\hline $\begin{array}{l}\text { Platypodium elegans } \\
\text { (Fabaceae) }\end{array}$ & Panama & - & 0.78 & A & Large bees & $\geq 750 \mathrm{~m}$ ( $25 \%$ of pollen $)$ & {$[52]$} \\
\hline $\begin{array}{l}\text { Tachigali versicolor } \\
\text { (Fabaceae) }\end{array}$ & Panama & - & - & A & Large bees & $\geq 750 \mathrm{~m}(21 \% \geq 500 \mathrm{~m})$ & {$[52,82]$} \\
\hline $\begin{array}{l}\text { Glyricidia sepium } \\
\text { (Fabaceae) }\end{array}$ & Guatemala & $\geq 10$ & 0.37 & M & Large bees (Xylocopa) & $275 \mathrm{~m} \max$ & {$[27]$} \\
\hline $\begin{array}{l}\text { Symphonia globulifera } \\
\text { (Clusiaceae) }\end{array}$ & $\begin{array}{l}\text { French } \\
\text { Guiana }\end{array}$ & $\geq 10$ & 10.9 & M & $\begin{array}{l}\text { Perching birds, } \\
\text { hummingbirds }\end{array}$ & 27 and $53 \mathrm{~m}(\mathrm{TG}) \mathrm{FG}$ & [28] \\
\hline Ceiba pentandra (Malvaceae) & Brazil & $\geq 90$ & 0.001 & M & Bats (Phyllostomus) & $\geq 18 \mathrm{~km}$ & [46] \\
\hline Ficus dugandii (Moraceae) & Panama & - & 0.004 & A & $1-2 \mathrm{~mm}$ wasps & 14.2 km (10.9-16.9) & [93] \\
\hline $\begin{array}{l}\text { Ficus obtusifolia } \\
\text { (Moraceae) }\end{array}$ & Panama & - & 0.072 & A & $1-2 \mathrm{~mm}$ wasps & $5.8 \mathrm{~km}(5.2-6.4)$ & [93] \\
\hline Ficus popenoei (Moraceae) & Panama & - & 0.013 & A & $1-2 \mathrm{~mm}$ wasps & 9.7 km (7.7-11.4) & {$[93]$} \\
\hline
\end{tabular}

Density (column 4) refers to trees in the size categories in col. 3. The genetic markers (col. 5) are allozymes (A) and microsatellite DNA (M). Maximum reported pollen dispersal distances (i.e. outside of the study plot) are preceded by $\geq$ or indicated by "max" if it is the maximum value for precisely measured gene flow events; mean values are indicated for studies employing the TwoGener method (TG). The technique used to infer pollen dispersal in Ficus is described in the main text.

${ }^{a}$ Diameter at breast height (in centimeters) of studied trees

Hence, fig reproduction involves a combination of wind and animal-mediated pollination.

The massive, bat-pollinated kapok tree Ceiba pentandra (Malvaceae) may hold the record for long distance animal pollination. Ceiba pentandra occurs in naturally low population densities along a narrow strip of nutrient-rich varzea (seasonally flooded) forest along the Amazon River. These varzea populations have been further reduced by logging and agricultural expansion. Because of their massive sizes, Gribel and colleagues were able to perform an aerial survey of large kapok trees in a peninsular area in the vicinity of Manaus, and collect leaves for paternity analyses using microsatellites. The authors found evidence of inter-tree pollen flow up to $18 \mathrm{~km}$ (Gribel, MS in prep) within this scattered population.

\section{Breakdown of Nearest Neighbor Mating}

A common observation in studies of low population density tree populations is the breakdown of nearest-neighbor mating. Stacy et al. [118] found that most pollination of clumped individuals of Calophyllum longifolium (Clusiaceae) involved nearest neighbors, which reflects the expected foraging pattern of bees and small insects. Where the trees were distributed more randomly across the forest inventory plot, on the other hand, pollinators bypassed nearest neighboring trees and dispersed pollen hundreds of meters. In the pasture population of Pithecellobium elegans, insect pollinators bypassed as many as ten more proximal trees on average [19]; similar patterns were found for the remnant legume tree Hymenaea courbaril in Puerto Rico 
[36], and for Dinizia excelsa in Brazil [30]. Asynchronous flowering, as well as pollen carryover, may account for the breakdown in nearest neighbor mating. The pasture population of Dinizia excelsa, however, exhibited complete overlap in flowering phenology. Another explanation for the breakdown of nearest neighbor foraging is that small insects can only perceive flowering trees within some distance threshold, beyond which they may fly in a random direction until they encounter another flowering tree.

\section{Seed vs Pollen Dispersal}

In tropical as well as temperate zone trees, gene flow by pollen is thought to be more extensive than gene flow by seed $[49,100]$. This is supported by circumstantial data for many tree species (but see [8]). However, the rule may not apply to some ecologically important tropical tree taxa. A parentage analysis in the dioecious tree Aucoumea klaineana (Burseraceae), where $87 \%$ of parents could be inferred, revealed similar mean dispersal distances for pollen (128 m, insect pollination) and seeds $(118 \mathrm{~m}$, wind dispersed; Born et al. [15]). Many other dioecious tree species have tiny flowers, but their fleshy fruits may be dispersed long distances by birds, bats and monkeys. Murray [90] found that Neotropical birds with generalist dietary preferences, such as those that visit Neotropical nutmg (Virola), disperse seeds $>500 \mathrm{~m}$. These studies raise the possibility that seed dispersal may be more extensive than pollen dispersal for some tropical tree species. Genetic studies of other dioecious tropical tree taxa will enable us to distinguish the relative contributions of seed and pollen mediated gene flow. The answer may deviate from expectations based largely on wind-pollinated temperate zone trees.

\section{Fine Scale Spatial Genetic Structure}

The indirect approach to estimating local gene flow entails inference from the fine scale spatial genetic structure (SGS, the non-random spatial distribution of genotypes) of adult or small individuals [57]. Fine scale SGS, characterized by a decrease of relatedness between individuals with distance, is often interpreted as seed dispersal limitation. Under scenarios of long distance seed dispersal with limited pollen flow, there should be no structure, primarily because closely related individuals (full or half sibs) will be broadly spaced. On the other hand, restricted seed dispersal is always expected to produce fine scale structure even if pollen movement is random and long distance because sibs will be aggregated. However, the dominant impact of seed dispersal over pollen dispersal on SGS occurs only over a spatial scale in the range of the bulk of seed dispersal (e.g. [58]). Beyond this scale, isolation-by-distance models at drift-dispersal equilibrium predict SGS: kinship between individuals should decrease linearly with the logarithm of the distance at a rate inversely proportional to the squared parent-offspring distance. At such a scale, both pollen and seed dispersal patterns are important. Some SGS analyses are based on this property to obtain indirect inferences of seed and pollen mediated gene dispersal (e.g. [57]).

Comparing the SGS of ten tree species in French Guiana, Hardy et al. [57] found lower SGS in species producing seeds that are presumably far dispersed (by birds, bats, arboreal mammals or wind in the case of light seeds) than in species likely suffering limited seed dispersal (by gravity, scatter-hoarding rodents or wind in the case of heavy seeds). In addition, SGS-based estimates of gene dispersal distances were higher in species with low local densities, a possible impact of density-dependent pollen dispersal distances. Because spatial aggregation of individuals is generally associated with limited seed dispersal among tropical forest trees, Hardy et al. [57] suggest that limited seed dispersal might often favor limited pollen dispersal.

Based on the rate of decay of relatedness with the logarithm of distance ( $S p$ statistic), Vekemans and Hardy [124] compared the fine scale SGS of 47 plant species (17 tree species), inferring significant impact of life-forms, mating system and density. We searched the literature for additional studies for which the $S p$ statistic could be calculated for tree species in order to compare fine scale SGS of temperate and tropical forest trees. Our survey was restricted to studies conducted within two-dimensional populations (inventory plots rather than linear transects) and sampled over a spatial scale in the range 0.5 to $10 \mathrm{~km}$.

Based on this survey, we found no significant differences in SGS between temperate zone trees $(S p=0.0166 ; N=24)$ and tropical trees $(S p=0.0173 ; N=15)$. Temperate species show a significant impact of the pollination vector $(t$ test: $P=0.018)$ : mean $S p=0.010 \quad(N=15)$ under wind dispersal, mean $S p=0.029(N=8)$ under animal dispersal. Tropical species were all animal-pollinated but a significant impact of seed dispersal is detected ( $t$ test: $P=0.027$ ): mean $S p=$ $0.009(N=6)$ for seeds primarily dispersed by birds, bats or monkeys, mean $S p=0.023(N=9)$ for seeds primarily dispersed by gravity, wind and/or scatter-hoarding rodents (Table 3). A similar trend occurs in temperate animalpollinated species but the difference is not significant $(t$ test: $P=0.15)$ : mean $S p=0.018 \quad(N=4)$ for seeds primarily dispersed by birds, mean $S p=0.035(N=5)$ for seeds primarily dispersed by gravity, wind and/or ground mammals. Although additional studies are necessary to confirm these trends, they suggest that the strength of local SGS can broadly be predicted from the efficiency of seed dispersal. 
Table 3 Fine scale spatial genetic structure (SGS) in tropical trees ( $S p$ statistic)

\begin{tabular}{|c|c|c|c|c|c|c|c|c|}
\hline Tree species (family) & Site & $\begin{array}{l}\text { d.b.h. adult } \\
\mathrm{cm}^{\mathrm{a}}\end{array}$ & $D$ & Marker & Pollinator & Seed Dispersal & $S p^{\mathrm{b}}$ & Reference \\
\hline $\begin{array}{l}\text { Aucoumea klaineana } \\
\text { (Burseraceae) }\end{array}$ & Gabon & $\geq 30$ & 1.87 & SSR & Insects & Wind & $0.013^{\mathrm{c}}$ & {$[15]$} \\
\hline Carapa procera (Meliaceae) & $\begin{array}{l}\text { French } \\
\text { Guiana }\end{array}$ & $\geq 17$ & 4.13 & RAPD & Insects & Rodents & 0.028 & {$[57]$} \\
\hline Carapa procera (Meliaceae) & $\begin{array}{l}\text { French } \\
\text { Guiana }\end{array}$ & $\geq 10$ & 6.43 & Allozymes & Insects & Rodents & 0.0012 & {$[34]$} \\
\hline Carapa guianensis (Meliaceae) & Brazil & $\geq 30$ & 2.5 & SSR & Insects & Gravity & 0.0045 & {$[20,21]$} \\
\hline $\begin{array}{l}\text { Chrysophyllum sanguinolentum } \\
\text { (Sapotaceae) }\end{array}$ & $\begin{array}{l}\text { French } \\
\text { Guiana }\end{array}$ & $\geq 25$ & 1.84 & $\begin{array}{r}\text { RAPD, } \\
\text { AFLP }\end{array}$ & Insects, bats & $\begin{array}{l}\text { Vertebrates } \\
\text { (monkeys) }\end{array}$ & 0.014 & {$[57]$} \\
\hline $\begin{array}{l}\text { Dicorynia guianensis } \\
\text { (Fabaceae) }\end{array}$ & $\begin{array}{l}\text { French } \\
\text { Guiana }\end{array}$ & $\geq 22$ & 3.60 & RAPD & Insects & Gravity, rodents & 0.019 & {$[57]$} \\
\hline $\begin{array}{l}\text { Dicorynia guianensis } \\
\text { (Fabaceae) }\end{array}$ & $\begin{array}{l}\text { French } \\
\text { Guiana }\end{array}$ & $\geq 22$ & 3.51 & RAPD & Insects & Gravity, rodents & 0.011 & {$[57]$} \\
\hline $\begin{array}{l}\text { Eperua grandiflora } \\
\text { (Fabaceae) }\end{array}$ & $\begin{array}{l}\text { French } \\
\text { Guiana }\end{array}$ & $\geq 27$ & 1.79 & $\begin{array}{r}\text { RAPD, } \\
\text { AFLP }\end{array}$ & Insects & Gravity & 0.016 & {$[57]$} \\
\hline $\begin{array}{l}\text { Jacaranda copaia } \\
\text { (Bignoniaceae) }\end{array}$ & $\begin{array}{l}\text { French } \\
\text { Guiana }\end{array}$ & $\geq 20$ & 0.75 & RAPD & Insects & Wind & 0.004 & {$[57]$} \\
\hline $\begin{array}{l}\text { Jacaranda copaia } \\
\text { (Bignoniaceae) }\end{array}$ & $\mathrm{BCI}$ & $\geq 20$ & 3.5 & SSR & Insects & Wind & 0.013 & {$[67]$} \\
\hline $\begin{array}{l}\text { Moronobea coccinea } \\
\text { (Clusiaceae) }\end{array}$ & $\begin{array}{l}\text { French } \\
\text { Guiana }\end{array}$ & $\geq 20$ & 1.63 & RAPD & Hummingbird & Gravity & 0.053 & {$[57]$} \\
\hline Sextonia rubra (Lauraceae) & $\begin{array}{l}\text { French } \\
\text { Guiana }\end{array}$ & $\geq 29$ & 1.73 & $\begin{array}{l}\text { SSR, } \\
\text { RAPD }\end{array}$ & Insects & Birds & 0.005 & {$[57]$} \\
\hline Sextonia rubra (Lauraceae) & $\begin{array}{l}\text { French } \\
\text { Guiana }\end{array}$ & $\geq 29$ & 0.74 & SSR & Insects & Birds & 0.000 & {$[57]$} \\
\hline $\begin{array}{l}\text { Simarouba amara } \\
\text { (Simaroubaceae) }\end{array}$ & $\mathrm{BCI}$ & $\geq 20$ & 2.4 & $\begin{array}{l}\text { AFLP, } \\
\text { SSR }\end{array}$ & Insect & Vertebrate & 0.0076 & {$[55]$} \\
\hline $\begin{array}{l}\text { Symphonia globulifera } \\
\text { (Clusiaceae) }\end{array}$ & $\begin{array}{l}\text { French } \\
\text { Guiana }\end{array}$ & $\geq 17$ & 6.1 & $\begin{array}{l}\text { SSR, } \\
\text { RAPD }\end{array}$ & $\begin{array}{l}\text { Perching birds, } \\
\text { hummingbird }\end{array}$ & $\begin{array}{l}\text { Vertebrates } \\
\text { (bats) }\end{array}$ & 0.017 & {$[57]$} \\
\hline Virola michelii (Myristicaceae) & $\begin{array}{l}\text { French } \\
\text { Guiana }\end{array}$ & $\geq 24$ & 1.01 & $\begin{array}{l}\text { RAPD, } \\
\text { AFLP }\end{array}$ & Insects & Birds, kinkajou & 0.015 & {$[57]$} \\
\hline $\begin{array}{l}\text { Vouacapoua americana } \\
\text { (Fabaceae) }\end{array}$ & $\begin{array}{l}\text { French } \\
\text { Guiana }\end{array}$ & $\geq 20$ & 6.27 & $\begin{array}{l}\text { SSR, } \\
\text { RAPD }\end{array}$ & Insects & Rodents & 0.032 & {$[57]$} \\
\hline $\begin{array}{l}\text { Vouacapoua americana } \\
\text { (Fabaceae) }\end{array}$ & $\begin{array}{l}\text { French } \\
\text { Guiana }\end{array}$ & $\geq 20$ & 4.16 & $\begin{array}{l}\text { SSR, } \\
\text { RAPD }\end{array}$ & Insects & Rodents & 0.010 & {$[57]$} \\
\hline $\begin{array}{l}\text { Vouacapoua americana } \\
\text { (Fabaceae) }\end{array}$ & $\begin{array}{l}\text { French } \\
\text { Guiana }\end{array}$ & $\geq 20$ & 5 & SSR & Insects & Rodents & 0.022 & {$[37]$} \\
\hline
\end{tabular}

The density $(D)$ is based on the size class indicated in column $3{ }^{a}$ Diameter at breast height (in centimeters) at reproductive maturity of studied tree species.

${ }^{\mathrm{b}}$ When SGS of a same population has been studied with several markers, the mean $S p$ value is reported.

${ }^{\mathrm{c}}$ Mean value over six sites

\section{Regional Differentiation}

The high levels of gene flow and genetic diversity found in local studies of tropical trees suggest that populations may have little genetic differentiation over regional spatial scales. In a comparative review of allozyme studies, however, tropical trees showed relatively high levels of population differentiation $\left(F_{\mathrm{ST}}=0.119 ; N=26\right.$ studies $)$ compared to trees of temperate forests $\left(F_{\mathrm{ST}}=0.092 ; N=125\right)$ or (especially) boreal forests $\left(F_{\mathrm{ST}}=0.038 ; N=40 ;[54]\right)$. To further evaluate regional differentiation in tropical trees, we searched the literature for studies reporting measures of genetic differentiation among populations $\left(F_{\mathrm{ST}}\right)$ of angiosperm trees $(\geq 10 \mathrm{~m}$ height $)$ using nuclear genetic markers (mostly allozymes or microsatellites). Only those studies focusing on broad geographic patterns (i.e. $>50 \mathrm{~km}$ ) were included. The studied species were then classified according to the position of the core of their range into tropical, subtropical, temperate and boreal. We searched for information on the typical stature of these trees, as reported in 
various sources (original papers or online databases), in order to evaluate Givnish's [44] hypothesis of greater differentiation in understory trees. We also compiled information on mode of pollination (biotic vs abiotic). We focused on the comparison between lowland tropical and temperate trees (supplemental material). A bilateral Student $t$ test (without assuming homoscedasticity) was used to compare $F_{\mathrm{ST}}$ of tropical and temperate taxa.

Our analysis included twice as many tropical species as the previous review [54]. It confirms that tropical trees have more genetic differentiation among populations $\left(F_{\mathrm{ST}}=\right.$ 0.177; $N=42$ species) than their counterparts in the temperate zone $\left(F_{\mathrm{ST}}=0.116 ; N=82, P=0.007\right)$. The difference stems in part from a number of tropical trees that display very high $F_{\mathrm{ST}}$ (Fig. 1). There was no significant difference in the degree of regional genetic differentiation between understory and canopy trees.

In contrast to the early predictions of Corner [25], Baker [9] and Federov [38], several decades of genetic research have shown that tropical forest trees are predominantly outcrossed, have extensive gene flow, and maintain high levels of genetic diversity. Nevertheless, our analysis found that tropical trees tend to have higher population genetic differentiation than their temperate zone counterparts. Ironically, this may be due to the fact that tropical trees do in fact experience higher levels of inbreeding than temperate zone trees, as a result of the association between low population density, density dependent animal pollination, and mixed mating systems. In our database, $53 \%$ of temperate tree species were animal-pollinated compared to
$92 \%$ of tropical trees. If wind-pollinated taxa are excluded, the difference in $F_{\mathrm{ST}}$ between tropical and temperate regions becomes non-significant: 0.145 for temperate $(N=$ 44) vs 0.179 for tropical $(N=39)$. In addition, the contrast between genetic structure of temperate and tropical trees seemed to be impacted by a handful of species with strong genetic structure around biogeographic barriers. Such cases are likely to become more frequent in the literature, as researchers expand upon the spatial scales of genetic research in tropical trees. The additional factor that may explain the higher-level differentiation in some cases was also recognized by early authors - the low population densities may impart a more substantial role of genetic drift in tropical compared to temperate zone tree species.

\section{Perspectives}

Future studies may bring the possibility of correlating gene dispersal distances with specific categories of pollinators. Our review showed a trend in differences in pollination distances of small bees vs medium to large bees, and long pollen dispersal distance mediated by bats and fig wasps. Most of the reviewed studies relied on published observations of floral visitors, or on educated guesses of pollinator identity based on the floral syndrome. Pollinator composition varies over space and time, and this heterogeneity can produce different patterns of gene flow [32, 70]. In order to make more precise links between pollination vector and gene flow distances, future
Fig. $1 F_{\mathrm{ST}}$ estimates over broad spatial scales in tropical and temperate zone trees

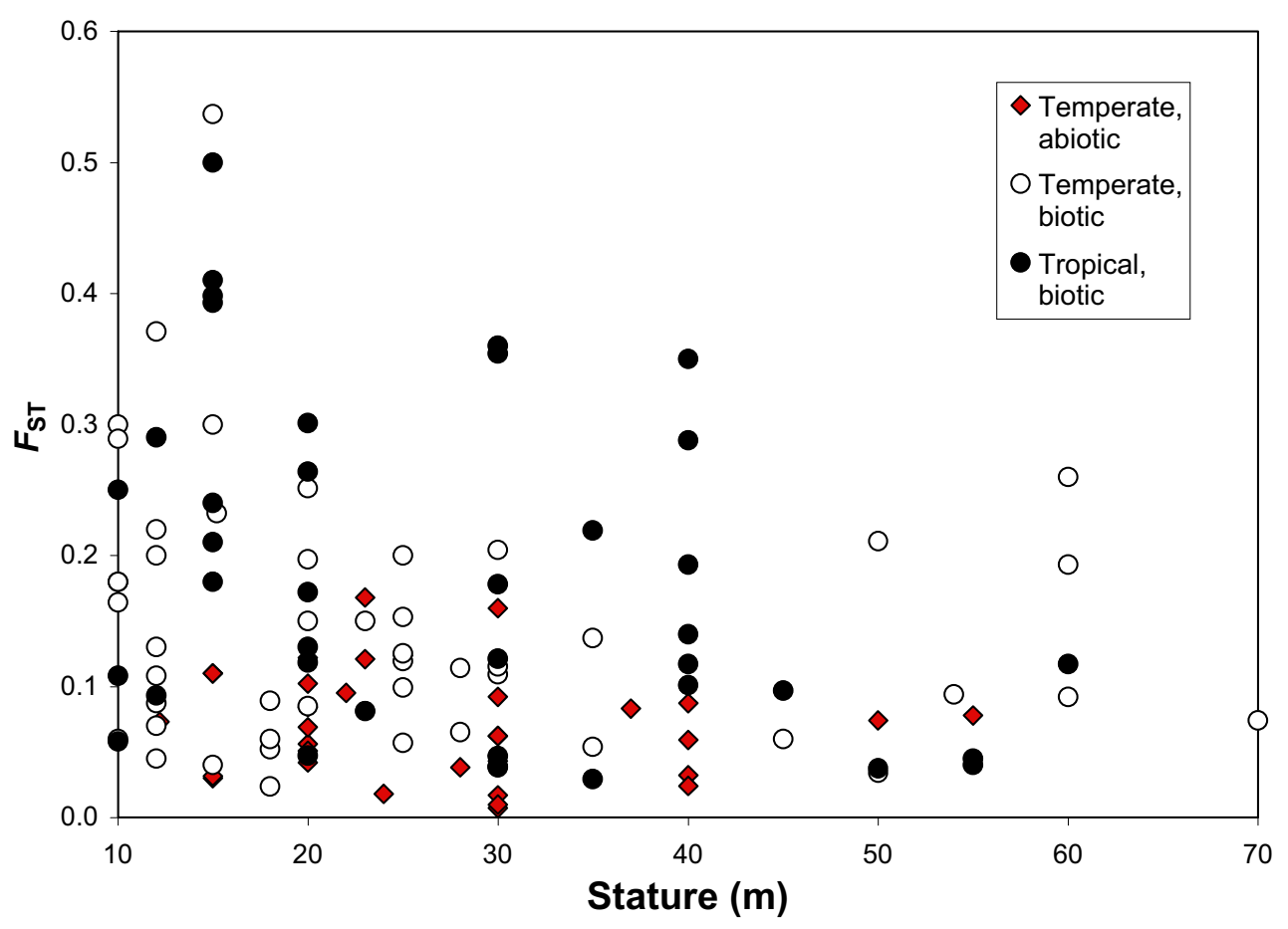


studies should incorporate pollinator observations of their study populations.

With an expanded dataset on population structure for tropical trees, it should also be possible to test for associations between pollen vector and $F_{\mathrm{ST}}$. It is worth noting that some studies of bat-pollinated trees have found low $F_{\mathrm{ST}}$ over broad geographic scales [33, 109, 114]. Given the long distance flight of fig wasp pollinators, fig species may also have relatively low $F_{\mathrm{ST}}$. There are not yet studies of broad scale population structure of Ficus species, however, despite the existence of approximately 750 species of Ficus worldwide, many of which have broad geographic distributions.

It should also be a priority to link observations of seed disperser assemblages with genetic marker-based tracking of seed dispersal distances. In a study of dispersal distances of different vertebrate seed dispersers of temperate trees, Jordano et al. [69] found that the rarest animals (mammals), rather than birds, were responsible for the most distant dispersal of seeds. Changes of disperser assemblages are likely to result in different spatial distributions and genetic structure of the host plants. Studies of protected and hunted forests have already shown different patterns of dispersal [97, 127]. Quantification of seed dispersal will also help to understand the impacts of climate change on tropical tree species distributions. As Hamrick [50] points out, pollen movement may be extensive enough in trees to allow for the exchange of adaptive genetic variation in response to changing climatic conditions. However, because colonization of new areas can only occur through seed movement, understanding the potential movement of seeds will help predict if plant populations can expand through migration into suitable habitats over the next few generations.

Acknowledgments CWD is supported by the National Science Foundation (DEB 064039) and the European Union (SEEDSOURCE INPA subcontract). RJP is supported by the European Union (EVOLTREE Network of Excellence and the SEEDSOURCE project, FP62002-INCO-DEV-1) as well as the Institut Français de la Biodiversité. FAJ is supported by the Smithsonian Tropical Research Institute with a Tupper Post-doctoral Fellowship and by the National Science Foundation (DEB 043665). OJH is supported by the Fonds de la Recherche Scientifique - FNRS (Belgium). We would like to thank three anonymous reviewers for useful suggestions.

\section{References}

1. Aide TM (1986) The influence of wind and animal pollination on variation in outcrossing rates. Evolution 40(2):434-435

2. Aldrich PR, Hamrick JL (1998) Reproductive dominance of pasture trees in a fragmented tropical forest mosaic. Science 281 (5373):103-105
3. Alvarez-Buylla ER, Garcia-Barrios R, Lara-Moreno C, MartinezRamos M (1996) Demographic and genetic models in conservation biology: applications and perspectives for tropical rain forest tree species. Ann Rev Ecol Syst 27:387-421

4. Appanah S (1985) General flowering in the climax rain forest of Southeastern Asia. J Trop Ecol 1:225-240

5. Apsit VJ, Hamrick JL, Nason JD (2001) Breeding population size of a fragmented population of a Costa Rican dry forest tree species. J Hered 92(5):415-420

6. Ashton PS (1969) Speciation among tropical forest trees: some deductions in the light of recent evidence. Biol J Linn Soc $1: 155-196$

7. Ashton PS, Givnish TJ, Appanah S (1988) Staggered flowering in the Dipterocarpaceae - new insights into floral induction and the evolution of mast fruiting in the aseasonal tropics. Am Nat 132(1):44-66

8. Bacles CFE, Lowe AJ, Ennos RA (2006) Effective seed dispersal across a fragmented landscape. Science 311 (5761):628-628

9. Baker HG (1959) Reproductive methods as factors in speciation in flowering plants. Cold Spr Harb Symp Quant Biol 24:177-199

10. Barrett SCH, Eckert CG (1990) Current issues in plant reproductive biology. Israel J Bot 39(1-2):5-12

11. Bawa KS (1990) Plant-pollinator interactions in tropical rainforests. Ann Rev Ecol Syst 21:399-422

12. Bawa KS, Opler PA (1975) Dioecism in tropical forest trees. Evolution 29(1):167-179

13. Bawa KS, Opler PA (1977) Spatial relationships between staminate and pistillate plants of dioecious tropical forest trees. Evolution 31(1):64-68

14. Bawa KS, Perry DR, Beach JH (1985) Reproductive biology of tropical lowland rainforest trees. 1. sexual systems and incompatibility mechanisms. Am J Bot 72(3):331-345

15. Born C, Hardy OJ, Chevalier MH, Ossari S, Attéke EJW, Hossaert-Mckey M (2008) Small-scale spatial genetic structure in the central African rainforest tree species Aucoumea klaineana: a stepwise approach to infer the impact of limited gene dispersal, population history and habitat fragmentation. Mol Ecol (in press) DOI 10.1111/j.1365-294X.2007.03685.x

16. Boshier DH, Chase MR, Bawa KS (1995) Population genetics of Cordia alliadora (Boraginaceae), a neotropical tree. 3. Gene flow, neighborhood, and population substructure. Am J Bot 82 (4):484-490

17. Bullock SH (1994) Wind pollination of neotropical dioecious trees. Biotropica 26(2):172-179

18. Cascante A, Quesada M, Lobo JJ, Fuchs EA (2002) Effects of dry tropical forest fragmentation on the reproductive success and genetic structure of the tree Samanea saman. Cons Biol 16 (1):137-147

19. Chase MR, Moller C, Kesseli R, Bawa KS (1996) Distant gene flow in tropical trees. Nature 383(6599):398-399

20. Cloutier D, Hardy OJ, Caron H, Ciampi AY, Degen B, Kanashiro M, Schoen DJ (2007a) Low inbreeding and high pollen dispersal distances in populations of two Amazonian forest tree species. Biotropica 39(3):406-415

21. Cloutier D, Kanashiro M, Ciampi AY, Schoen DJ (2007b) Impact of selective logging on inbreeding and gene dispersal in an Amazonian tree population of Carapa guianensis Aubl. Mol Ecol 16(4):797-809

22. Collevatti RG, Grattapaglia D, Hay JD (2001) High resolution microsatellite based analysis of the mating system allows the detection of significant biparental inbreeding in Caryocar brasiliense, an endangered tropical tree species. Heredity 86:60-67 
23. Condit R, Ashton PS, Baker P, Bunyavejchewin S, Gunatilleke S, Gunatilleke N, Hubbell SP, Foster RB, Itoh A, LaFrankie JV, Lee HS, Losos E, Manokara N, Sukumar R, Yamakura T (2000) Spatial patterns in the distribution of tropical tree species. Science 288:1414-1418

24. Connell JH (1971) On the role of natural enemies in preventing competitive exclusion in some marine animals and in rain forest trees. In: den Boer PJ, Gradwell GR (eds) Dynamics of populations. Centre for Agricultural Publishing and Documentation, Wageningen, pp 298-313

25. Corner EJH (1954) The evolution of tropical forests. In: Huxley J, Hardy AC, Ford EC (eds) Evolution as a process. Allen and Unwin, London, pp 34-46

26. da Silva Carneiro F, Sebbenn AM, Kanashiro M, Degen B (2007) Low interannual variation of mating system and gene flow of Symphonia globulifera in the Brazilian Amazon. Biotropica 39(5):628-636

27. Dawson IK, Waugh R, Simons AJ, Powell W (1997) Simplesequence repeats provide a direct estimate of pollen-mediated gene dispersal in the tropical tree Gliricidia sepium. Mol Ecol 6:179-183

28. Degen B, Bandou E, Caron H (2004) Limited pollen dispersal and biparental inbreeding in Symphonia globulifera in French Guiana. Heredity 93(6):585-591

29. Diamond JM, Gilpin ME, Mayr E (1976) Species-distance relation for birds of the Solomon archipelago, and the paradox of the great speciators. Proc Natl Acad Sci U S A 73:2160-2164

30. Dick CW (2001) Genetic Rescue of Remnant Tropical Trees by an Alien Pollinator. Proc Roy Soc Lond Ser B Biol Sci 268:2391-2396

31. Dick CW, Abdul-Salim K, Bermingham E (2003a) Molecular systematics reveals cryptic Tertiary diversification of a widespread tropical rainforest tree. Am Nat 162(12):691-703

32. Dick CW, Etchelecu G, Austerlitz F (2003b) Pollen dispersal of tropical trees (Dinizia excelsa: Fabaceae) by native insects and African honeybees in pristine and fragmented Amazonian rainforest. Mol Ecol 12(3):753-765

33. Dick CW, Bermingham E, Lemes MR, Gribel R (2007) Extreme long distance dispersal of the lowland rainforest tree Ceiba pentandra L. (Malvaceae) in Africa and the Neotropics. Mol Ecol 16:3039-3049

34. Doligez A, Joly HI (1997a) Genetic diversity and spatial structure within a natural stand of a tropical forest tree species, Carapa procera (Meliaceae), in French Guiana. Heredity 79: $72-82$

35. Doligez A, Joly HI (1997b) Mating system of Carapa procera (Meliaceae) in the French Guiana tropical forest. Am J Bot 84 (4):461-70

36. Dunphy BK, Hamrick JL, Schwagerl J (2004) A comparison of direct and indirect measures of gene flow in the bat-pollinated tree Hymenaea courbaril in the dry forest life zone of southwestern Puerto Rico. Intl J Plant Sci 165(3):427-436

37. Dutech C, Seiter J, Petronelli P, Joly HI, Jarne PI (2002) Evidence of low gene flow in a neotropical clustered tree species in two rainforest stands of French Guiana. Mol Ecol 11:725-738.

38. Fedorov AA (1966) The structure of the tropical rain forest and speciation in the humid tropics. J Ecol 54(1):1-11

39. Franceschinelli EV, Bawa KS (2000) The effect of ecological factors on the mating system of a South American shrub species (Helicteres brevispira). Heredity 84(1):116-123

40. Frankie GW, Haber WA (1983) Why bees move among massflowering neotropical trees. In: Jones CE, Little RJ (eds) Handbook of experimental pollination biology. Van Rostrand Reinhold, New York, pp 360-372

41. Fuchs EJ, Lobo JA, Quesada M (2003) Effects of forest fragmentation and flowering phenology on the reproductive success and mating patterns of the tropical dry forest tree Pachira quinata. Cons Biol 17(1):149-157

42. Gan YY, Robertson FW, Ashton PS, Soepadmo E, Lee DW (1977) Genetic variation in wild populations of rain-forest trees. Nature 269(5626):323-325

43. Gentry AH (1982) Patterns of neotropical plant species diversity. Evol Biol 15:1-84

44. Givnish TJ (1999) On the causes of gradients in tropical tree diversity. J Ecol 87:193-210

45. Goodwillie C, Kalisz S, Eckert CG (2005) The evolutionary enigma of mixed mating systems in plants: occurrence, theoretical explanations, and empirical evidence. Ann Rev Ecol Evol Syst 36:47-79

46. Gribel R, Lemes MR (1997) Mating system and pollen flow of Ceiba pentandra (Bombacaceae) in Central Amazon Assessment of levels and dynamics of intra-specific genetic diversity of tropical trees. Second Annual Report to the European Commission.

47. Hall P, Orrell L, Bawa KS (1994) Genetic diversity and mating system in a tropical tree, Carapa guianensis (Meliaceae). Am J Bot 81(9):1104-1111

48. Hall P, Walker S, Bawa KS (1996) Effect of forest fragmentation on genetic diversity and mating system in a tropical tree, Pithecellobium elegans. Cons Biol 10(3):757-768

49. Hamilton MB, Miller JR (2002) Comparing relative rates of pollen and seed gene flow in the island model using nuclear and organelle measures of population structure. Genetics 162 (4):1897-1909

50. Hamrick JL (2004) Response of forest trees to global environmental changes. For Ecol Man 197(1-3):323-335

51. Hamrick JL, Loveless MD (1989) Genetic structure of tropical tree populations: associations with reproductive biology. In: Bock JH, Linhart YB (eds) Evolutionary ecology of plants. Westview, Boulder, pp 129-146

52. Hamrick JL, Murawski DA (1990) The breeding structure of tropical tree populations. Plant Spec Biol 5:157-165

53. Hamrick JL, Godt MJW (1996) Effects of life history traits on genetic diversity in plant species. Phil Trans Roy Soc Lond Ser B Biol Sci 351(1345):1291-1298

54. Hamrick JL, Godt MJW, Sherman-Broyles SL (1992) Factors influencing levels of genetic diversity in woody plant species. New Forests 6:95-124

55. Hardesty BD, Dick CW, Kremer A, Hubbell SP, Bermingham E (2005) Spatial genetic structure of Simarouba amara Aubl. (Simaroubaceae), a dioecious, animal dispersed tree, on Barro Colorado Island, Panama. Heredity 95:290-297

56. Hardesty BD, Hubbell SP, Bermingham E (2006) Genetic evidence of frequent long-distance recruitment in a vertebratedispersed tree. Ecol Let 9(5):516-525

57. Hardy OJ, Maggia L, Bandou E, Breyne P, Caron H, Chevallier MH, Doligez A, Dutech C, Kremer A, Latouche-Halle C, Troispoux V, Veron V, Degen B (2006) Fine-scale genetic structure and gene dispersal inferences in 10 Neotropical tree species. Mol Ecol 15(2):559-571

58. Heuertz M, Vekemans X, Hausman JF, Palada M, Hardy OJ (2003) Estimating seed vs. pollen dispersal from spatial genetic structure in the common ash. Mol Ecol 12(9):2483-2495

59. Howe HF (1977) Bird activity and seed dispersal of a tropical wet forest tree. Ecology 58(3):539-550

60. Howe HF, Smallwood J (1982) Ecology of seed dispersal. Ann Rev Ecol Syst 13:201-228

61. Hubbell SP (2001) The unified neutral theory of biodiversity and biogeography. Princeton University Press, Princeton

62. Hubbell SP, Foster RB (1983) Diversity of canopy trees in a neotropical forest and implications for conservation. In: Sutton SL, Whitmore TC, Chadwick AC (eds) Tropical rain forest: 
ecology and management. Blackwell Scientific, Oxford, pp 25-41

63. Hufford KM, Hamrick JL (2003) Viability selection at three early life stages of the tropical tree, Platypodium elegans (Fabaceae, Papilionoideae). Evolution 57(3):518-526

64. Hurtt GC, Pacala SW (1995) The consequences of recruitment limitation - reconciling chance, history and competitive differences between plants. J Theor Biol 176(1):1-12

65. Janzen DH (1967) Synchronization of sexual reproduction of trees within dry season in Central America. Evolution 21 (3):620-637

66. Janzen DH (1970) Herbivores and the number of tree species in tropical forests. Am Nat 104:501-528

67. Jones FA, Hubbell SP (2006) Demographic spatial genetic structure of the Neotropical tree, Jacaranda copaia. Mol Ecol 15(11):3205-3217

68. Jones FA, Chen J, Weng G-J, Hubbell SP (2005) A genetic evaluation of seed dispersal in the neotropical tree Jacaranda copaia (Bignoniaceae). Am Nat 166(5):543-555

69. Jordano P, Garcia C et al (2007) Differential contribution of frugivores to complex seed dispersal patterns. Proc Natl Acad Sci U S A 104(9):3278-3282

70. Kenta T, Isagi Y, Nakagawa M, Yamashita M, Nakashizuka T (2004) Variation in pollen dispersal between years with different pollination conditions in a tropical emergent tree. Mol Ecol 13 (11):3575-3584

71. Koeniger N, Koeniger G (1980) Observations and experiments on migration and dance communication of Apis dorsata in Sri Lanka. J Apic Res 19:21-34

72. Konuma A, Tsumura Y, Lee CT, Lee SL, Okuda T (2000) Estimation of gene flow in the tropical-rainforest tree $\mathrm{NeO}$ balanocarpus heimii (Dipterocarpaceae), inferred from paternity analysis. Mol Ecol 9(11):1843-1852

73. Latouche-Hallé C, Ramboer A, Bandou E, Caron H, Kremer A (2004) Long-distance pollen flow and tolerance to selfing in a neotropical tree species. Mol Ecol 13(5):1055-1064

74. Lee SL (2000) Mating system parameters of Dryobalanops aromatica Gaertn. f. (Dipterocarpaceae) in three different forest types and a seed orchard. Heredity 85(4):338-345

75. Leigh EG, Davidar P, Dick CW, Puyravaud J-P, Terborgh J, Ter Steege H, Wright SJ (2004) Why do some tropical forests have so many kinds of trees? Biotropica 36(4):447-473

76. Levin DA, Kerster HW (1968) Local gene dispersal in Phlox. Evolution 22:130-139

77. Liengsiri C, Boyle TJB, Yeh FC (1998) Mating system in Pterocarpus macrocarpus Kurz in Thailand. J Hered 89(3):216-221

78. Linskens HF (1996) No airborne pollen within tropical rain forests. Proc Koninklijke Nederlandse Akademie Van Wetenschappen 99(3-4):175-180

79. Lobo JA, Quesada M, Stoner KE, Fuchs EJ, Herrerias-Diego Y, Rojas J, Saborio G (2003) Factors affecting phenological patterns of bombacaceous trees in seasonal forests in Costa Rica and Mexico. Am J Bot 90(7):1054-1063

80. Lobo JA, Quesada M, Stoner KE (2005) Effects of pollination by bats on the mating system of Ceiba pentandra (Bombacaceae) populations in two tropical life zones in Costa Rica. Am J Bot 92 (2):370-376

81. Lourmas M, Kjellberg F, Dessard H, Joly HI, Chevallier MH (2007) Reduced density due to logging and its consequences on mating system and pollen flow in the African mahogany Entandrophragma cylindricum. Heredity 99:151-160

82. Loveless MD, Hamrick JL, Foster RB (1998) Population structure and mating system in Tachigali versicolor, a monocarpic neotropical tree. Heredity 81:134-143

83. Lowe AJ, Boshier D, Ward M, Bacles CFE, Navarro C (2005) Genetic resource impacts of habitat loss and degradation; reconciling empirical evidence and predicted theory for neotropical trees. Heredity 95(4):255-273

84. Matallana G, Wendt T, Araugo DSD, Scarano FR (2005) High abundance of dioecious plants in a tropical coastal vegetation. Am J Bot 92(9):1513-1519

85. Momose K, Yumoto T, Nagamitsu T, Kato M, Nagamasu H, Sakai S, Harrison RD, Itioka T, Hamid AA, Inoue T (1998) Pollination biology in a lowland dipterocarp forest in Sarawak, Malaysia. I. Characteristics of the plant-pollinator community in a lowland dipterocarp forest. Am J Bot 85 (10):1477-1501

86. Muellner AN, Savolainen V, Samuel R, Chase MW (2006) The mahogany family "out-of-Africa": Divergence time estimation, global biogeographic patterns inferred from plastid rbcL DNA sequences, extant, and fossil distribution of diversity. Mol Phyl Evol 40(1):236-250

87. Murawski DA, Hamrick JL (1991) The effect of the density of flowering individuals on the mating systems of nine tropical tree species. Heredity $67: 167-174$

88. Murawski DA, Hamrick JL (1992) The mating system of Cavanillesia platanifolia under extremes of flowering tree density: a test of predictions. Biotropica 24:99-101

89. Murawski DA, Gunatilleke IAUN, Bawa KS (1994) The effects of selective logging on inbreeding in Shorea megistophylla (Dipterocarpaceae) from Sri Lanka. Cons Biol 8(4):997-1002

90. Murray KG (1988) Avian seed dispersal of three neotropical gapdependent plants. Ecol Mon 58:271-98

91. Nason JD, Hamrick JL (1997) Reproductive and genetic consequences of forest fragmentation: Two case studies of neotropical canopy trees. J Hered 88(4):264-276

92. Nason JD, Herre EA, Hamrick JL (1996) Paternity analysis of the breeding structure of strangler fig populations: Evidence for substantial long-distance wasp dispersal. J Biog 23(4): $501-512$

93. Nason JD, Herre EA, Hamrick JL (1998) The breeding structure of a tropical keystone plant resource. Nature 391 (6668):685-687

94. Nathan R (2006) Long distance dispersal of plants. Science 313:786-788

95. Nettel A, Dodd RS (2007) Drifting propagules and receding swamps: Genetic footprints of mangrove recolonization and dispersal along tropical coasts. Evolution 61(4):958-971

96. Obayashi K, Tsumura Y, Ihara-Ujino T, Niiyama K, Tanouchi H, Suyama Y, Washitani I, Lee CT, Lee SL, Muhammad N (2002) Genetic diversity and outcrossing rate between undisturbed and selectively logged forests of Shorea curtisii (Dipterocarpaceae) using microsatellite DNA analysis. International J Plant Sci 163 (1):151-158

97. Pacheco LF, Simonetti JA (2000) Genetic structure of a mimosoid tree deprived of its seed disperser, the spider monkey. Cons Biol 14(6):1766-1775

98. Pennington RT, Dick CW (2004) The role of immigrants in the assembly of the South American rainforest tree flora. Phil Trans Roy Soc Lond Ser B Biol Sci 359:1611-1622

99. Petit RJ, Hampe A (2006) Some evolutionary consequences of being a tree. Ann Rev Ecol Evol Syst 37:187-214

100. Petit RJ, Duminil J, Fineschi S, Hempe A, Salvini D, Vendramin GG (2005) Comparative organization of chloroplast, mitochondrial and nuclear diversity in plant populations. Mol Ecol 14 (3):689-701

101. Quesada M, Stoner KE, Lobo JA, Herrerias-Diego Y, PalaciosGuevara C, Munguia-Rosas MA, Salazar KAO, Rosas-Guerrero $\mathrm{V}$ (2004) Effects of forest fragmentation on pollinator activity and consequences for plant reproductive success and mating patterns in bat-pollinated bombacaceous trees. Biotropica 36 (2):131-138 
102. Ramirez N (2004) Ecology of pollination in a tropical Venezuelan savanna. Plant Ecol 173(2):171-189

103. Regal P (1977) Ecology and evolution of flowering plant dominance. Science 196:622-629

104. Renner SS (2004) Plant dispersal across the tropical Atlantic by wind and sea currents. Intl J Plant Sci 165(4 Suppl.):S23S33

105. Renner SS (2005) Relaxed molecular clocks for dating historical plant dispersal events. Tree 10(11):550-556

106. Ricklefs RE (2004) A comprehensive framework for global patterns in biodiversity. Ecol Let 7:1-15

107. Robledo-Arnuncio JJ, Austerlitz F, Smouse PE (2006) A new method of estimating the pollen dispersal curve independently of effective density. Genetics 173(2):1033-1045

108. Rocha OJ, Aguilar G (2001) Variation in the breeding behavior of the dry forest tree Enterolobium cyclocarpum (Guanacaste) in Costa Rica. Am J Bot 88(9):1600-1606

109. Roesel CS, Kress WJ, Bowdich BM (1996) Low levels of genetic variation in Phenakospermum guyannense (Strelitziaceae), a widespread, bat-pollinated Amazonian herb. Plant Syst Evol 199:1-15

110. Sakai S, Momose K, Yumoto T, Nagamitsu T, Nagamasu H, Hamid AA, Nakashizuka T (1999) Plant reproductive phenology over four years including an episode of general flowering in a lowland dipterocarp forest, Sarawak, Malaysia. Am J Bot 86 (10):1414-1436

111. Schemske DW, Lande R (1986) Mode of pollination and selection on mating system - comment. Evolution 40(2):436436

112. Schupp EW (1993) Quantity, quality and the effectiveness of seed dispersal by animals. Vegetatio 108:15-29

113. Sezen UU, Chazdon RL, Holsinger KE (2005) Genetic consequences of tropical second-growth forest regeneration. Science 307(5711):891-891

114. Shapcott A (1999) Vagility and the monsoon rain forest archipelago of northern Australia: Patterns of genetic diversity in Syzygium nervosum (Myrtaceae). Biotropica 31(4):579-590

115. Simpson GG (1940) Mammals and land bridges. J Wash Acad Sci 30:137-163

116. Smouse PE, Sork VL (2004) Measuring pollen flow in forest trees: an exposition of alternative approaches. Forest Ecol Man 197(1-3):21-38
117. Smouse PE, Dyer RJ, Westfall RD, Sork VL (2001) Twogeneration analysis of pollen flow across a landscape. I. male gamete heterogeneity among females. Evolution 55(2):260-271

118. Stacy EA, Hamrick JL, Nason JD, Hubbell SP, Foster RB, Condit R (1996) Pollen dispersal in low-density populations of three neotropical tree species. Am Nat 148(2):275-298

119. Stephenson AG (1982) When does outcrossing occur in a massflowering plant. Evolution 36(4):762-767

120. Tilman D (1994) Competition and biodiversity in spatially structured habitats. Ecology 75(1):2-16

121. Turner IM (2001) The ecology of trees in the tropical rain forest. Cambridge University Press, Cambridge

122. Valencia R, Foster RB, Villa G, Condit R, Svenning JC, Hernández C, Romoleroux K, Losos E, Magård E, Balslev H (2004) Tree species distributions and local habitat variation in the Amazon: large forest plot in eastern Ecuador. J Ecol 92:214-229

123. Vamosi JC, Otto SP, Barrett SCH (2003) Phylogenetic analysis of the ecological correlates of dioecy in angiosperms. J Evol Biol 16(5):1006-1018

124. Vekemans X, Hardy OJ (2004) New insights from fine-scale spatial genetic structure analyses in plant populations. Mol Ecol 13(4):921-935

125. Veron V, Caron H, Degen B (2005) Gene flow and mating system of the tropical tree Sextonia rubra. Silv Genet 54(6):275-280

126. Wallace AR (1878) Tropical nature and other essays. Macmillan, New York

127. Wang BC, Sork VL, Leong MT, Smith TB (2007) Hunting of mammals reduces seed removal and dispersal of the afrotropical tree Antrocaryon klaineanum (Anacardiaceae). Biotropica 39 (3):340-347

128. Ward M, Dick CW, Gribel R, Lowe AJ (2005) To self, or not to self... A review of outcrossing and pollen-mediated gene flow in neotropical trees. Heredity 95:246-254

129. Webb CJ, Bawa KS (1983) Pollen dispersal by hummingbirds and butterflies: a comparative study of two lowland tropical plants. Evolution 37:1258-1270

130. Wright SJ (2002) Plant diversity in tropical forests: a review of mechanisms of species coexistence. Oecologia 130(1):1-14

131. Zarate S, Perez-Nasser N, Casas A (2005) Genetics of wild and managed populations of Leucaena esculenta subsp esculenta (Fabaceae; Mimosoideae) in La Montana of Guerrero, Mexico. Genet Res Crop Evol 52(7):941-957 